\title{
Structure, food and shade attract juvenile coral reef fish to mangrove and seagrass habitats: a field experiment
}

\author{
M. C. Verweij ${ }^{1}$, I. Nagelkerken ${ }^{1, *}$, D. de Graaff $^{1}{ }^{,}$M. Peeters ${ }^{1}$, E. J. Bakker ${ }^{2}$, \\ G. van der Velde ${ }^{1}$ \\ ${ }^{1}$ Department of Animal Ecology and Ecophysiology, Radboud University Nijmegen, Institute for Water and Wetland \\ Research, Toernooiveld 1, 6525 ED Nijmegen, The Netherlands \\ ${ }^{2}$ Biometris, Department of Mathematical and Statistical Methods, University of Wageningen, Bornsesteeg 47, \\ 6708 PD Wageningen, The Netherlands
}

\begin{abstract}
Mangroves and seagrass beds are considered nurseries for juvenile fish, but little experimental evidence exists to elucidate which factors make them attractive habitats. A multifactorial field experiment on the use of these habitats by juvenile reef fish and their behaviour was performed during daytime with experimental units (EUs: $1 \times 1 \times 0.8 \mathrm{~m}$ ), each representing a unique combination of the factors structure, shade, and food, using artificial seagrass leaves (AS) and artificial mangrove roots (AM). Diurnally active herbivores were most abundant in EUs containing food, and grazed on algae growing on the structures, but were not attracted to structures in the absence of food. The most abundant diurnally active zoobenthivores (Eucinostomus spp.) were present in highest numbers in any EU with food, where they fed on zoobenthos or rested on the bottom. The nocturnally active zoobenthivore/zooplanktivore Ocyurus chrysurus and the diurnally active piscivore Sphyraena barracuda were primarily attracted to structure, in which they rested and were not observed to feed. Haemulon flavolineatum was mainly attracted to AS, Lutjanus mahogoni was attracted to AS or shade, whereas L. apodus, O. chrysurus and S. barracuda were found in AM as well as in AS. The data suggest that during daytime, herbivores and diurnally active zoobenthivores are probably attracted to mangroves and seagrass beds primarily by food, and nocturnally active zoobenthivores by structure (in interaction with shade) that offers shelter from predation. S. barracuda is also attracted primarily to structure, but the larger individuals probably use this for ambush predation rather than for protection. In conclusion, our experiment clarifies that presence of structure, food and shade significantly contribute to the attractiveness of mangroves and seagrass beds to juvenile reef fish.
\end{abstract}

KEY WORDS: Artificial mangrove roots - Artificial seagrass - Coral reef fish - Shelter habitat · Feeding habitat $\cdot$ Habitat utilisation $\cdot$ Behaviour $\cdot$ Caribbean

\section{INTRODUCTION}

Mangroves and seagrass beds are assumed to function as nursery habitats for a variety of reef fish species (Parrish 1989, Jackson et al. 2001, Heck et al. 2003), though direct evidence of connectivity between juvenile and adult habitats has seldom been provided (Beck et al. 2001, Gillanders et al. 2003, Chittaro et al. 2004).
Although mangroves and seagrass beds harbour high numbers of various juvenile reef fish, little is known about the factors determining this. It has been suggested that the main reasons why mangroves and seagrass beds may be attractive to juvenile fish are low predator abundance, presence of structure, high food availability, low predation efficiency of predators, and a high interception of planktonic fish larvae due to the 
extensive surface area of mangroves and seagrass beds (Orth et al. 1984, Pollard 1984, Schulman 1985, Parrish 1989, Blaber 2000, Laegdsgaard \& Johnson 2001).

The frequency of encounter rates with piscivores is higher on the coral reef than at $20 \mathrm{~m}$ away from the reef (Schulman 1985); hence shallow water habitats, such as mangroves and seagrasses, are believed to contain less piscivores than the reef (Blaber \& Blaber 1980, Parrish 1989, Ronnback et al. 1999). However, Sheaves (2001) argued that there is little unequivocal evidence for this theory. Structure provides fish with shelter, but also with food (Laegdsgaard \& Johnson 2001). Food is abundant in mangroves and seagrass beds and is present in the form of invertebrates attracted to structure or hiding in the sediment, seagrass leaves, algae, and epibionts associated with seagrass leaves and mangrove roots (e.g. Orth et al. 1984, Orth \& van Montfrans 1984, Pollard 1984, Howard et al. 1989, Parrish 1989, Ley et al. 1994, Tomascik et al. 1997, Valentine \& Heck 1999, Nagelkerken et al. 2000). Fish are also attracted to mangroves by the presence of decomposing mangrove leaves, which possibly function as a food source to detritivores (Odum \& Heald 1975, Rajendran \& Kathiresan 1999). Predation efficiency on fishes and shrimps is negatively affected by the structural complexity of seagrass beds (e.g. Heck \& Thoman 1981, Orth et al. 1984, Rooker et al. 1998, Hindell et al. 2000, Stunz \& Minello 2001) and mangroves (Primavera 1997, Laegdsgaard \& Johnson 2001). The mere presence of structure does not necessarily provide protection; the density of structural units and species-specific behaviour of both predator and prey should be taken into account (Main 1987). For example, presence of mangrove pneumatophores did not decrease predation efficiency of an actively hunting fish predator on shrimps, whereas it did reduce predation on shrimps by a more passive fish predator (Primavera 1997). Water turbidity can also negatively affect predator efficiency due to scattering and reduction of light by suspended particles (Blaber \& Blaber 1980, Benfield \& Minello 1996).

A factor that has seldom been investigated, and may be partly responsible for the attraction of fish to mangroves and seagrass beds, is shade. Shade is provided by long seagrass leaves and, more importantly, by an extensive roof of branches and leaves of mangroves above the water surface. Shade is believed to reduce predation risk (Helfman 1981, Cocheret de la Morinière et al. 2004). For example, predation by the ambush predator Hippocampus erectus on shrimps in seagrass beds decreased under shaded conditions (James \& Heck 1994), and visual prey detection by piscivorous salmonids of their prey decreased with decreasing light levels (Mazur \& Beauchamp 2003). In experimental pools, bluegills Lepomis macrochirus used shaded areas when a predator was in open unshaded waters, but avoided shade when the predator was in the shade (McCartt et al. 1997). In artificial mangrove units, juvenile reef fish preferred shaded over unshaded units (Cocheret de la Morinière et al. 2004).

Few experiments have studied which factors attract fish to mangroves and seagrass beds, and a multifactorial design has seldom been applied. Such an experimental study on several combined factors can unravel effects of single factors, their interactions, and a possible hierarchy in their attractiveness. So far, only 2 field studies have partially attempted multifactorial investigation by using artificial mangrove roots: Laegdsgaard \& Johnson (2001) studied the interactive effects between food and shelter, while Cocheret de la Morinière et al. (2004) focused on structure and shade. A third multifactorial study used living mangrove roots in the laboratory and tested the factors of turbidity, prey density, substrate type and pneumatophore density on the predation of thorn fish Terapon jarbua on shrimp (Macia et al. 2003). Multifactorial experiments in (artificial) seagrass beds on factors attracting fish have been conducted more often (e.g. Bell \& Westoby 1986, Edgar 1999, Levin et al. 1997, Levin \& Hay 2003).

The majority of field studies mentioned above have investigated only 1 or 2 factors in 1 experimental design; the attractiveness of mangroves and seagrass beds has not yet been studied simultaneously. In the present study, we applied a multifactorial design to study the interactive effects of 4 different factors in a single experiment: structure, shade, food and habitat type (artificial mangrove roots and artificial seagrass leaves). Because little is known of the behaviour of fishes within such artificial habitats, we studied this as well. Here, we tested the hypothesis that fish species of different feeding guilds probably make use of mangroves and seagrass beds during daytime for different reasons. We expected that nocturnally active fish species use mangroves and seagrass beds as shelter habitats during daytime, whereas diurnally active fish species use these habitats as feeding grounds.

\section{MATERIALS AND METHODS}

Study area. The study was carried out in December 2003, in the Spanish Water Bay (total surface area approx. $3 \mathrm{~km}^{2}$ ) in south-western Curaçao, Netherlands Antilles (Fig. 1). The bay has a narrow entrance $(70 \mathrm{~m}$ wide) and a $1.1 \mathrm{~km}$ long and 11 to $18 \mathrm{~m}$ deep channel that connects the bay to the sea and a fringing coral reef. The main part of the bay is relatively shallow $(<6$ $\mathrm{m}$ deep). The mean daily tidal range is about $30 \mathrm{~cm}$ (de Haan \& Zaneveld 1959). Besides rainwater, the bay has no freshwater input. Seagrass beds and (macro-) algal 


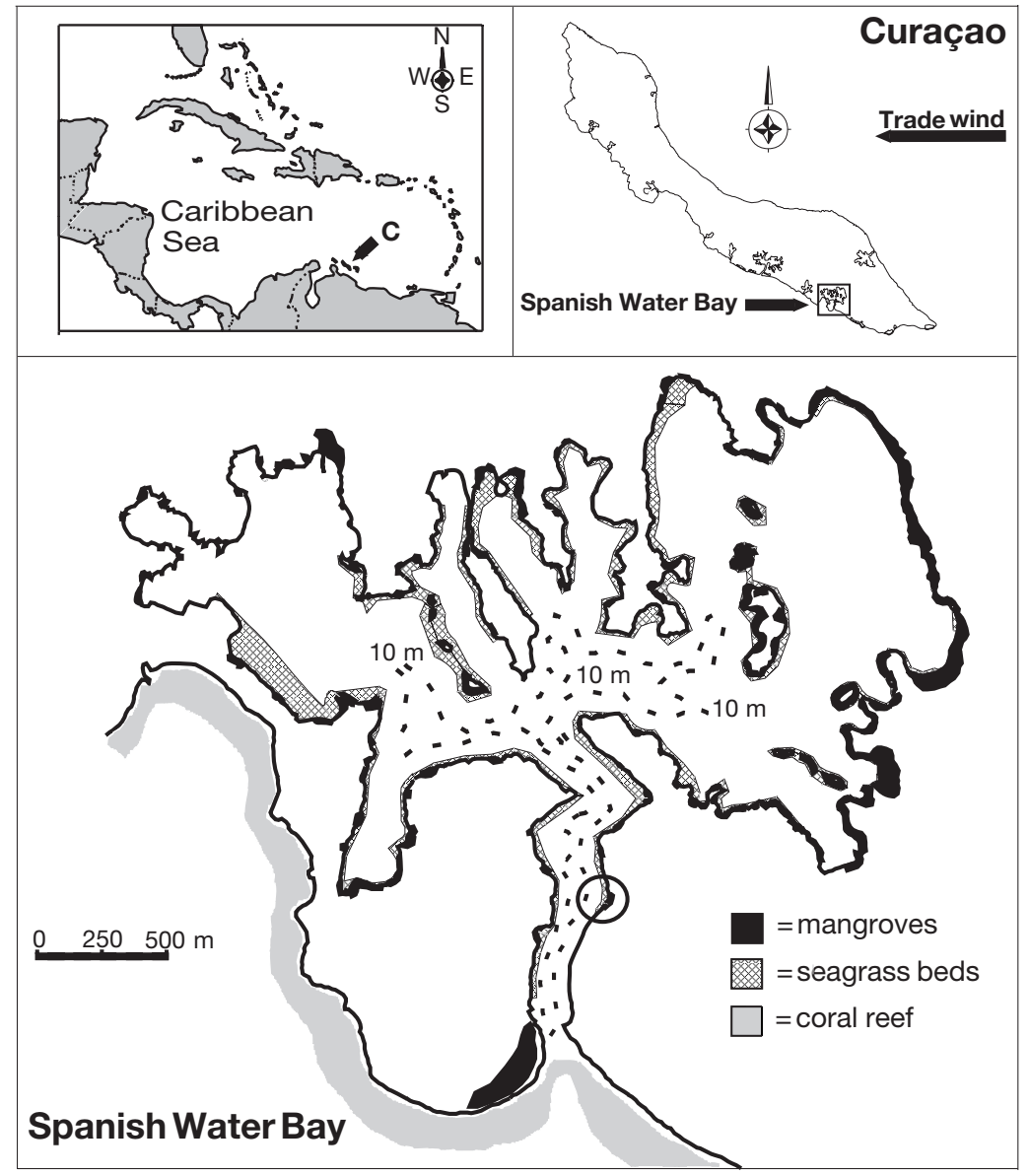

Fig. 1. Map of the Spanish Water Bay at Curaçao $\left({ }^{\prime} \mathrm{C}^{\prime}\right)$ indicating the location of the study site (encircled)

flats cover the bottom of the bay. The shoreline consists partly of fossil coral reef and is fringed by mangroves, dominated by the red mangrove Rhizophora mangle. The experiment was carried out near an isolated mangrove stand adjacent to a seagrass bed (Fig. 1). The mangrove stand was approximately $36 \mathrm{~m}$ long and $3 \mathrm{~m}$ wide and consisted solely of $R$. mangle. The mangroves were separated from the adjacent seagrass bed Thalassia testudinum by a strip of muddy substratum approximately $3 \mathrm{~m}$ wide. Mean $( \pm \mathrm{SD})$ seagrass density of this seagrass bed was $289.0 \pm 222.1 \mathrm{~m}^{-2}$, and mean leaf length was $19.7 \pm 1.0 \mathrm{~cm}$. Mean water clarity at the study site was $7.0 \pm 1.1 \mathrm{~m}$, as measured by horizontal Secchi disk distance. Mean water depth at the outer mangrove border was $97.6 \pm 6.6 \mathrm{~cm}$.

Experimental design. Experimental units (EUs) were constructed with iron rods (1 $\mathrm{m}$ long, $6 \mathrm{~mm}$ in diameter, see Cocheret de la Morinière et al. 2004). The lower vertical $20 \mathrm{~cm}$ of the iron rods protruded from the bottom of the EU and could be pushed into the sediment (Fig. 2a). Above the sediment, the open EUs were
$1.0 \mathrm{~m}$ wide, $1.0 \mathrm{~m}$ long and $0.8 \mathrm{~m}$ high. In total, 16 EUs were used (Fig. 2b). Each EU represented a unique combination of the factors structural complexity (artificial mangrove roots = AM, artificial seagrass leaves = AS, both AM and AS, or neither), shade (present or absent), and food in the form of fouling algae and access to zoobenthos (present or absent).

PVC pipes (diameter $1.5 \mathrm{~cm}$, length $40 \mathrm{~cm}$ ) mimicked mangrove proproots. A density of pipes of $64 \mathrm{~m}^{-2}$ was chosen because in a previous study, highest fish abundances were found in EUs with this level of structural complexity (Cocheret de la Morinière et al. 2004). The PVC pipes were evenly distributed in an EU by suspending them from nylon twine lines which were tied to the upper horizontal iron ribs (Fig. 2a). In this way, they mimicked aerial mangrove prop-roots hanging in the water column, as is the case for mangroves in Spanish Water Bay.

Artificial plastic Thalassia testudinum leaves of width $9 \mathrm{~mm}$ and length $19 \mathrm{~cm}$ (Pangea Rocks APS) were evenly distributed and attached to an iron grid (density 200 leaves $\mathrm{m}^{-2}$ ) on the bottom of an EU by using copper staples. Leaf lengths and densities of artificial seagrass were similar to those in the natural seagrass bed (see above). Upston \& Booth (2003) showed that fish assemblages in natural and artificial seagrass beds are comparable.

Shade was created by covering the top of the EU with black shading fabric (polyethylene monofilament). The shading cloth was always submerged. Underwater light intensities were measured at 10:00, 12:30 and 14:00 h by a snorkelling observer holding a Li-Cor light meter at arm length depth. This way, light intensities were measured at approximately $30 \mathrm{~cm}$ above the substratum under natural conditions (above the muddy substratum adjacent to the mangroves in full sunlight, at the mangrove rim, and $0.5 \mathrm{~m}$ inside the mangroves) and in the centre of EUs with different types of structure and/or shade in the top part (empty EUs, shade only, AM only, AM and shade). Because algae growing on the shading cloth probably decreased light intensity, the shading cloth of all EUs with the treatment 'shade' was cleaned every day.

Presence of food for herbivores was created in the EUs by natural growth of algae on the PVC pipes, the ribs of the EUs, and the artificial seagrass leaves. The EUs 'with 

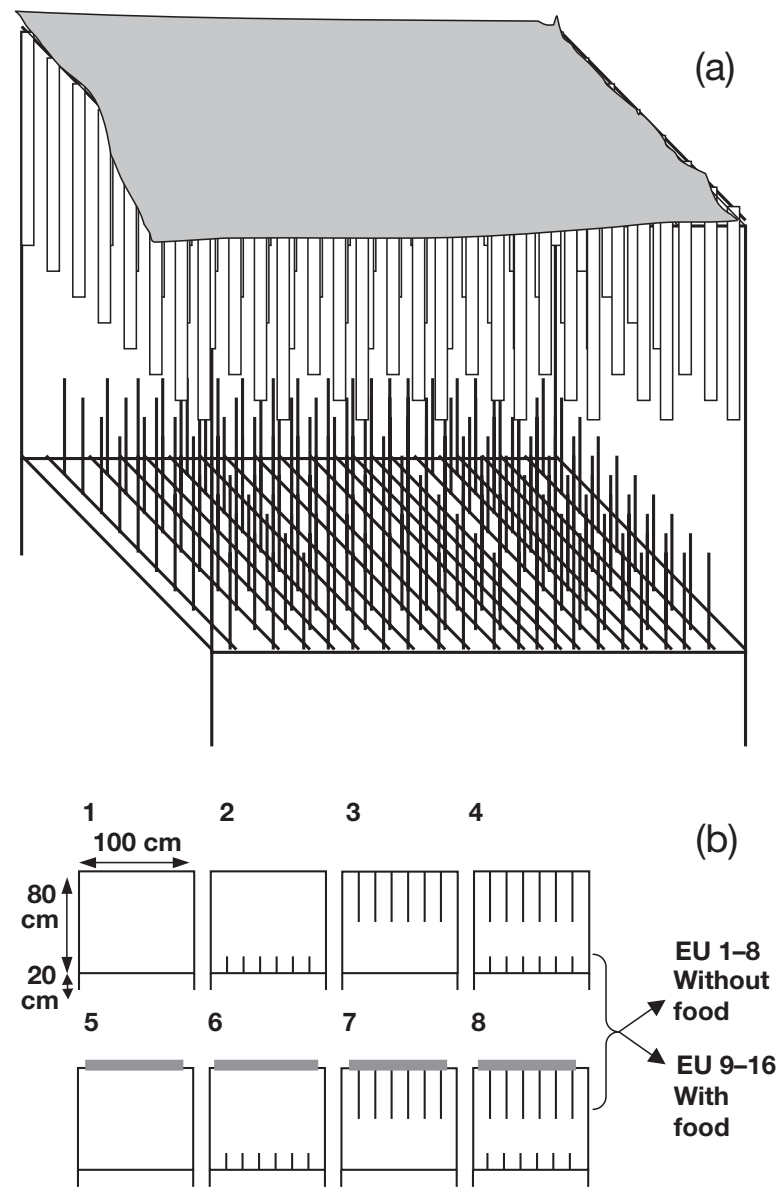

(c)

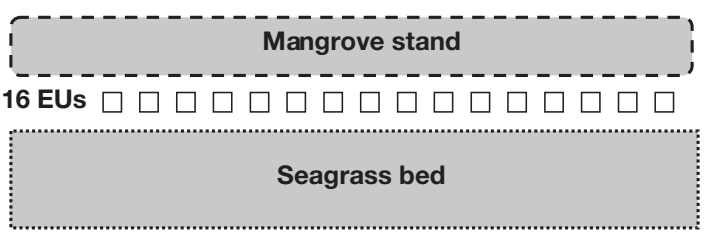

Fig. 2. (a) Schematic drawing of an experimental unit (EU) with artificial mangrove roots, artificial seagrass leaves, and shade. (b) Schematic representation of the 16 treatments. Vertical bars at top of EU represent artificial mangrove roots and vertical bars at bottom of EU represent artificial seagrass leaves. Horizontal grey bars above EUs represent presence of shade. Food was either absent (EUs 1 to 8) or present in the form of fouling algae and access to zoobenthos in the sediment (EUs 9 to 16). (c) Placement of EUs in the field

food' were placed in the field for a minimum of $20 \mathrm{~d}$ and a maximum of $32 \mathrm{~d}$ before the actual start of the experiment, during which algae had time to grow. The presence of the fouling algae on the EUs attracted small crustaceans. The crustaceans on the EU structures and in the sediment on the bottom of the EUs (which was freely accessible in the EUs 'with food', see next paragraph) served as a food source for zoobenthivores.
For all EUs 'without food', algal growth was removed from the EUs every $2 \mathrm{~d}$ during the experiment. EUs were always cleaned at the end of the day after the last observation. Moreover, the bottom of all EUs 'without food' was covered by a cotton sheet, so that zoobenthivores were not able to forage in the sediment. It should be noted that in all EUs, presence/absence of food only refers to presence/absence of algae and macrozoobenthos, and not to that of prey fish in the case of piscivores.

In the field, the EUs were lined up in a randomised order, on a muddy substratum bordered by the mangrove stand on one side and the seagrass bed on the other side (Fig. 2c). The muddy substratum did not contain any natural submerged aquatic vegetation which could add additional structure to the bottom of the EUs. A distance of $1 \mathrm{~m}$ was maintained between an EU and the mangrove and seagrass border, and between EUs. Before observations started, EUs were left undisturbed for $3 \mathrm{~d}$ after placement in the field.

Observations. Observations took place at 3 time intervals during daytime: from 10:00 to 10:45 h (T1), from 11:30 to $12: 15 \mathrm{~h}$ (T2), and from 13:00 to $13: 45 \mathrm{~h}$ (T3). Observations were carried out by 2 observers using snorkelling gear. The observers each started at one end of the line-up of EUs and then swam in the opposite direction to each other. One observer swam between the EUs and the mangrove border, while the other swam between the EUs and the seagrass border. After surveying all EUs, observers waited for a period of 5 min, after which a second observation round started in which the 16 EUs were surveyed again. Each observer carried out 4 observation rounds per time interval, resulting in a total of 8 observations per time interval, per day, per EU. All fishes inside the EU at the moment of observation were identified, their numbers were counted, and individual sizes were estimated in $2.5 \mathrm{~cm}$ length classes. The behaviour of each fish (resting, feeding, swimming, aggressive interactions, and hunting) and its location inside the EU (bottom, mid-water, top) were recorded by one of the trained observers. Each EU was observed daily for 3 consecutive days, during which time they remained in the same randomised order in the field. EUs were put in a new randomised order after the last observation on every 3rd day, in order to diminish possible effects of location in the line of EUs. Every 4th d (i.e. day after randomly reordering EUs), EUs were left to rest and no observations took place. In total, EUs were placed in 8 different random orders (configurations) and were observed for $3 \mathrm{~d}$ per configuration. Water depth was measured at the beginning of each observation round. EUs were completely submerged during all observations; at all times water levels were higher than $80 \mathrm{~cm}$. 
Data analysis. Because Eucinostomus jonesii and E. gula were difficult to discriminate under water, these 2 species were recorded as 'Eucinostomus spp.'. All other fishes could be determined to species-level. For the data analysis, all encountered fish species were subdivided into 5 feeding guilds that were either diurnally or nocturnally active (following Randall 1967, Carr \& Adams 1973). Mean fish numbers were calculated per EU (treatment) for each feeding guild and for the most abundant species within each guild. The 8 configurations were regarded as replicates through time per treatment. Fish numbers were calculated by (1) taking the mean of the 8 observation rounds of the 2 observers per time interval for each day, which resulted in 9 values ( 3 time intervals of 3 consecutive days) for 8 configurations (replicates); (2) these 9 values were then averaged for each of the 8 replicates. Mean and SE shown in all figures were calculated from these 8 replicates.

Statistical analysis. Differences in light intensities under natural and experimental conditions were tested with a Mann-Whitney $U$-test, for the combinations 'full sunlight' measured above the muddy substratum versus 'empty, unshaded EU', and 'mangrove rim' versus 'EU with AM and shade', using the statistical programme SPSS 11.0.

Prior to statistical analysis, fish abundances were calculated by taking the sum of the 72 observations ( 8 observation rounds for 3 time intervals for 3 consecutive days) per treatment and per replicate, in order to maintain discrete values to enable a Poisson regression (McCullagh \& Nelder 1989). We pooled data from the 8 observation round because of their apparent dependency. The 3 time intervals and 3 d within 1 configuration were pooled for 2 reasons: (1) we were not interested in time or day effects, and (2) by pooling these values we did not have to make the (questionable) assumption of independent data between time intervals within $1 \mathrm{~d}$, or between days at the same time interval. The pooling process was the same as applied by Cocheret de la Morinière et al. (2004). Pooling resulted in 128 observations: 8 replicates (through time) for 16 treatments.

The data were counts and did not have a normal distribution due to the many 0 counts. EUs were relatively small compared to the vast expanses of natural mangroves and seagrass beds surrounding the EUs. As a result, the chance of encountering a fish inside an EU was small (explaining the 0 counts).

To test the main and interaction effects of structure, food and shade on fish abundances, a Poisson regression with a log-link function was performed for each feeding guild and the most abundant species, using the statistical programme Genstat 7.2. Since the observed counts tended to be overdispersed compared to Poisson variance, a correction was applied using the scaled deviance as an estimate for the dispersion parameter (McCullagh \& Nelder 1989). The model contained 1 dependent factor (fish abundance), 3 treatment factors (structure, food, and shade) with their interactions, and 2 blocks (replication through time and EU location). The EU location, although randomized in the experiment, was included because location effects were still possible. In order to test the main effects of the factor 'food' and 'shade' for the pooled herbivore species between 2 EUs with the same type of structure (with/without food, with/without shade), $t$-tests for pairwise differences (127 degrees of freedom) were performed for such a pair of EUs within the context of the Poisson regression.

\section{RESULTS}

\section{Light intensity}

Underwater light intensities measured in the field under natural and experimental conditions are shown in Table 1. Light intensities in full sunlight and in an empty EU were not significantly different $(p=0.749$, $Z=-0.320$, Mann-Whitney $U$-test) whereas the light intensity was significantly lower at the mangrove rim than in an EU with AM and shade ( $p=0.004, Z=$ -2.882, Mann-Whitney $U$-test).

\section{Fish abundance}

Table 2 shows the results of the Poisson regression for all feeding guilds and their most abundant species. In total, 15 fish species were encountered in the experimental EUs (see Table 3). Pooled abundances of diurnally active herbivores were significantly affected

Table 1. Light intensities $\left(\mu \mathrm{E} \mathrm{m}^{-2} \mathrm{~s}^{-1}\right.$; mean $\left.\pm \mathrm{SE}\right)$ measured under natural and experimental conditions. Light intensities in 'full sunlight' were measured above the muddy substratum adjacent to the mangroves. -: without + +: with. EU + AM: EU with artificial mangrove roots only. EU - AM: empty EUs and EUs with artificial seagrass leaves only

\begin{tabular}{|lc|}
\hline Condition & Light intensity \\
\hline Full sunlight & $1112 \pm 61$ \\
Mangrove rim & $109 \pm 25$ \\
Inside mangroves & $17 \pm 1$ \\
EU - AM - shade & $1149 \pm 70$ \\
EU - AM + shade & $386 \pm 27$ \\
EU + AM - shade & $1060 \pm 48$ \\
EU + AM + shade & $369 \pm 38$ \\
\hline
\end{tabular}


Table 2. Results of the Poisson regression for treatments 'structure' (struct), 'food' and 'shade', their interactions, and the blocks 'replicate through time' (rep) and 'location' (loc). Test results are given for the different feeding guilds (in bold) and for the most abundant species within each guild. D: diurnally active, $\mathrm{N}$ : nocturnally active. ns: not significant $(\mathrm{p}>0.05),{ }^{*} 0.01<\mathrm{p}<0.05$, ${ }^{* *} 0.001<\mathrm{p}<0.01,{ }^{* * *} \mathrm{p}<0.001$

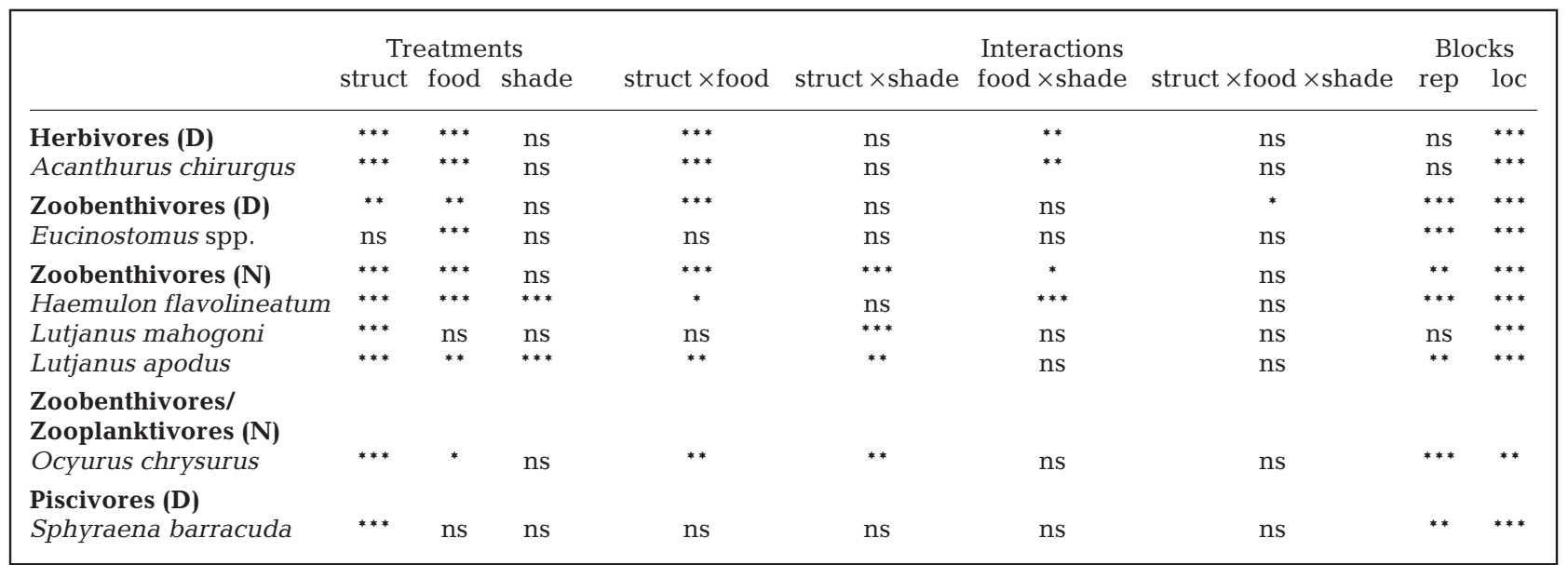

by the factors structure and food (Table 2), and significant interactions were present between structure and food and between food and shade (Table 2). When food was present (in the form of algae), numbers of herbivores increased with increasing structure surface in the order: AS only, AM only, and both AS and AM (Fig. 3a). In all EUs without food, fish numbers were similarly low for all levels of structure (Fig. 3a). In EUs containing AM only, herbivores were more abundant in EUs with food than in EUs without food (Fig. 3a, p < 0.001 for EUs 'without shade' and 'with shade', paired $t$-test). The same was true for EUs with both AM and AS when shade was absent $(\mathrm{p}=0.004$, paired $t$-test), but not true when shade was present $(p=0.854$, paired t-test) (Fig. 3a). Shade seemed to have a negative effect on herbivore abundances in EUs with food and AM structures, compared to the same EUs when unshaded (Fig. 3a); however, this effect was not significant (EU with AM only: $p=0.105$, and EU with AM and AS: $\mathrm{p}=0.097$; paired $t$-test). At species level, Acanthurus bahianus (Fig. 3b, Table 2), A. chirurgus and Scarus guacamaia showed the same trends as those of pooled herbivores.

Pooled abundances of diurnally active zoobenthivores were significantly affected by the interaction between structure and food, and by the 3-way interaction between structure, food and shade (Table 2). However, pooled diurnally active zoobenthivores seemed equally abundant for all levels of structure, food and shade (Fig. 4a). An exception was the EU without shade, without food and with AM only, where fish numbers were higher compared to the same EU with food because of high numbers of Gerres cinereus in 1 of the 8 replicates. As a result of this outlier the SE is very large (Fig. 4a). The most abundant diurnally active zoobenthivore species,
Eucinostomus spp., showed significantly higher numbers in EUs with food than in EUs without food (Fig. 4b, Table 2). Their abundances were not significantly affected by structure or shade (Fig. 4 b, Table 2).
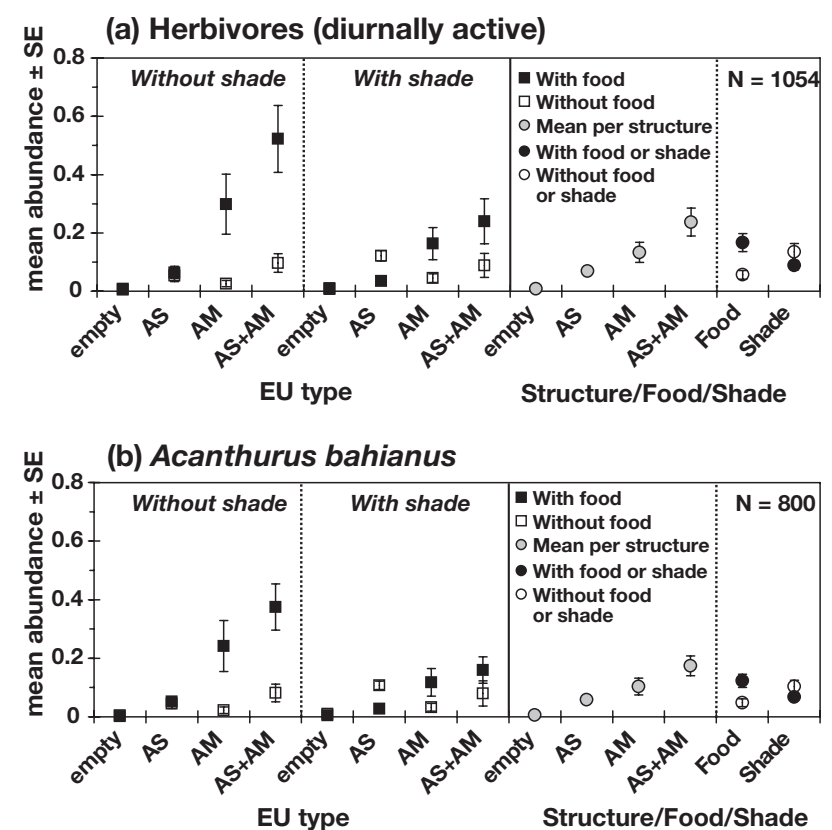

Fig. 3. Mean fish abundance for each treatment (left part) and for each level of the separate factors structure, food and shade (right part) of (a) pooled diurnally active herbivores and (b) Acanthurus bahianus. N: total sum of fishes of all observation rounds, time intervals and days. Left part shows all 16 EUs with and without food. Right part shows mean fish abundance in EUs for each structure type and in EUs with and without food. Empty $=$ EU without structure, AS = artificial seagrass leaves only, $\mathrm{AM}=$ artificial mangrove roots only, $\mathrm{AS}+\mathrm{AM}=$ artificial seagrass leaves and artificial mangrove roots. If the $\mathrm{SE}$ of the mean is not visible it is very small 
Pooled abundances of nocturnally active zoobenthivore species were significantly affected by structure and food, and significant interactions were present between structure and food, between structure and shade, and between food and shade (Table 2). Their abundances were highest in any type of EU containing AS (Fig. 5a). This was also observed at species level for Haemulon flavolineatum, Lutjanus mahogoni and Lutjanus apodus (Fig. 5b-d), but in the presence of shade this pattern disappeared for the latter 2 species that correspondingly showed significant interactions between structure and shade (Table 2). In presence of shade $L$. apodus showed higher numbers in EUs with any type of structure than in EUs without structure (Fig. 5d, Table 2); in contrast, in presence of shade, numbers of L. mahogoni were equally high in all EUs including the EU without structure (Fig. 5c, Table 2). $H$. flavolineatum and $L$. apodus were significantly affected by food, in interaction with shade and/or structure (Table 2). Numbers of $H$. flavolineatum and L. apodus were higher in AS EUs without food than in AS EUs with food (Fig. 5b,d), particularly in the presence of shade, which is attributable to reduced structural complexity of fouled AS (see 'Discussion'). These 2 highly abundant species were responsible for the significant effect of the factor food, and the significant interaction between food and structure and between food and shade, for the pooled nocturnally active zoobenthivores (Fig. 5a, Table 2).
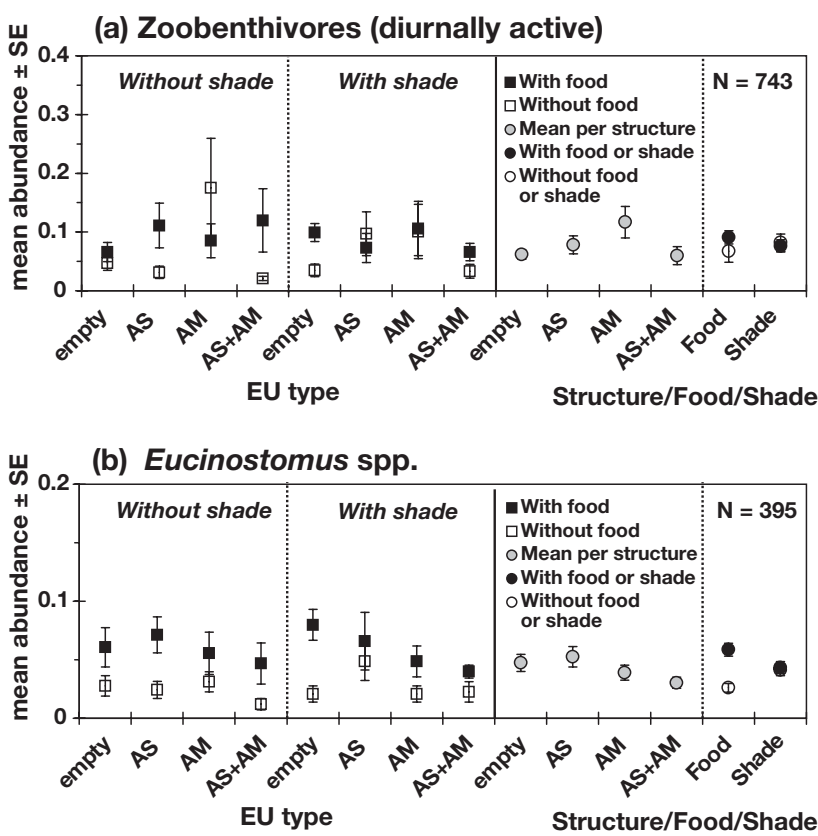

Fig. 4. Mean fish abundance for each treatment (left part) and for each level of the separate factors structure, food and shade (right part) of (a) pooled diurnally active zoobenthivores, and (b) Eucinostomus spp. See Fig. 3 legend for other details
Nocturnally active zoobenthivores/zooplanktivores were only represented by Ocyurus chrysurus. Abundances were significantly affected by the factors structure and food and by interactions between structure and food and between structure and shade (Table 2). Similar to the nocturnally active zoobenthivores, abundances of $O$. chrysurus were highest in any EU with AS when shade was absent (Fig. 6a). Just like H. flavolin-

(a) Zoobenthivores (nocturnally active)

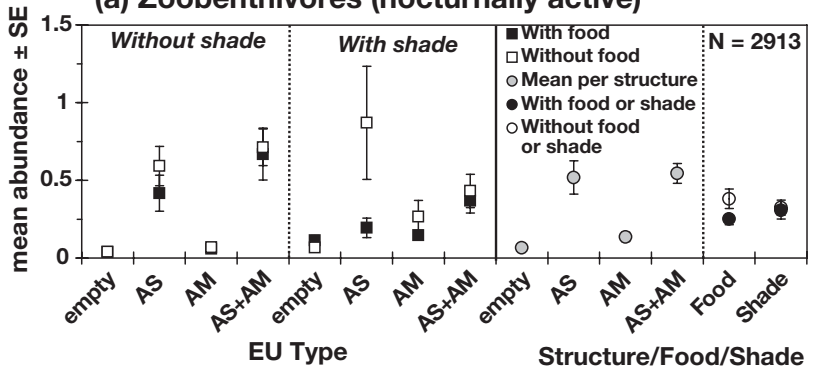

(b) Haemulon flavolineatum

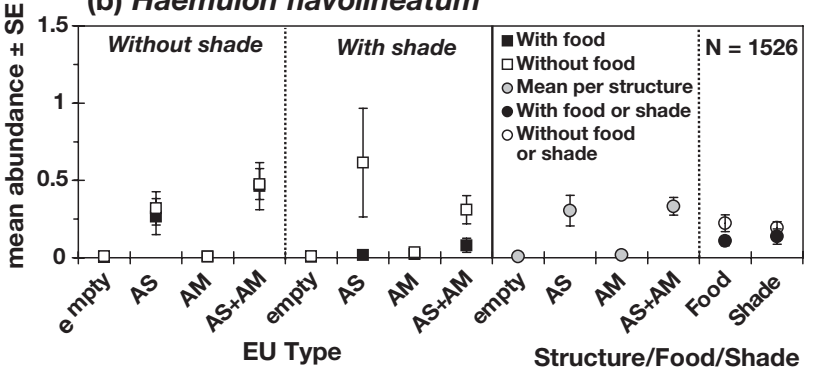

(c) Lutjanus mahogoni
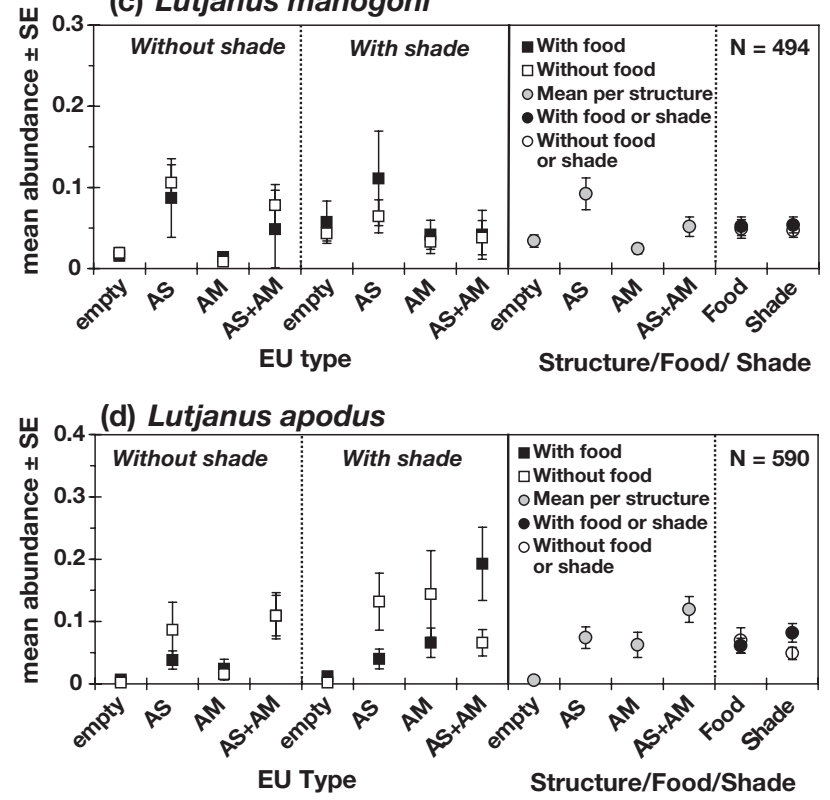

Fig. 5. Mean fish abundance for each treatment (left part) and for each level of the separate factors structure, food and shade (right part) of (a) pooled nocturnally active zoobenthivores, (b) Haemulon flavolineatum, (c) Lutjanus mahogoni, and (d) Lutjanus apodus. See Fig. 3 legend for other details 
eatum and L. apodus, numbers of $O$. chrysurus were higher in AS EUs without food than in AS EUs with food (Fig. 6a). As in the case of Lutjanus apodus, abundances of $O$. chrysurus in the presence of shade were higher in EUs with any type of structure compared to empty EUs (Fig. 6a).

Abundances of diurnally active piscivores, represented by Sphyraena barracuda, were only significantly affected by structure (Table 2). Abundances were higher in all EUs with structure than in empty EUs (Fig. 6b).

\section{Fish behaviour}

Herbivore fish species were mainly foraging in the EUs (69 to $92 \%$, Table 3). On average, herbivores grazed mostly on algae growing on AM (44 to $85 \%$ ), and less on algae growing on AS (6 to $23 \%$ ) and least on the bottom substratum (1 to $12 \%$ ). When comparing EUs with and without food, the percentage of herbivores foraging on AM was much higher in EUs with food $(67.4 \%)$ than in EUs without food $(1.5 \%)$, as would be expected. The percentage of herbivores foraging on AS was not higher in EUs with food $(17.0 \%)$ than in EUs without food (26.3\%), but the number of herbivores present in EUs with AS without food was on average 2.4 times lower than those present in EUs with AS with food, which should be kept in mind when interpreting the percentages.

Nocturnally and diurnally active zoobenthivores mostly rested in the EUs (94.9 and $72.2 \%$, respectively, Table 3). An exception was the diurnally active Mulloidichthys martinicus, which was searching for food on the substratum in $54.1 \%$ of the cases (Table 3 ), and did so in EUs both with and without food (40.5 and $67.4 \%$, respectively). Furthermore, Haemulon bonariense was actively swimming in and out of the EUs in $53.7 \%$ of the cases. All zoobenthivorous species rested on the bottom of the EUs, except for Lutjanus apodus that also rested (i.e. hovered) in the upper part of the EU (Table 3).

Most specimens of the nocturnally active zoobenthivore/zooplanktivore Ocyurus chrysurus and the piscivorous Sphyraena barracuda rested in the EUs (80.7 and $98.2 \%$, respectively). In contrast to the zoobenthivores, they rested on the bottom, in the middle, and also in the upper part of the EUs (Table 3). When this effect was separated for type of structure, the following pattern was observed: when only AS was present, they rested mostly in between the artificial leaves (bottom of EU, 70.0 to $90.2 \%$ ); when only AM was present, they rested mostly in between the artificial roots (middle and top of the EU, 70.0 to $85.8 \%$ ); when both structures were present, they rested in between the leaves (32.6 (a) Ocyurus chrysurus

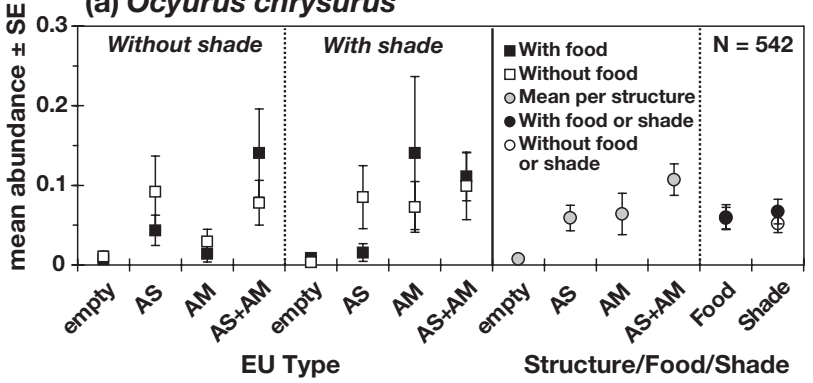

(b) Sphyraena barracuda

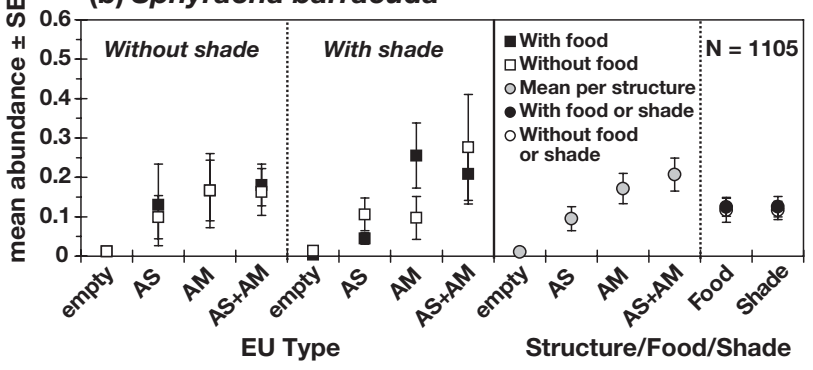

Fig. 6. Mean fish abundance for each treatment (left part) and for each level of the separate factors structure, food and shade (right part) of (a) nocturnally active zoobenthivores/zooplanktivores (Ocyurus chrysurus), and (b) diurnally active piscivores (Sphyraena barracuda). See Fig. 3 legend for other details

to $40.8 \%$ ) as well as in between the roots (45.6 to $65.6 \%)$. The same pattern was observed for Lutjanus apodus $(97.3,91.3$, and 49.6 vs. $50.5 \%$, respectively).

\section{DISCUSSION}

The experiment imparted 2 artefacts that should be considered when interpreting some data points in the figures. The artificial seagrasses could not be completely cleaned from calcareous algae, resulting in a few herbivores that also foraged on artificial seagrass leaves 'without food'. Secondly, some artificial seagrass leaves 'with food' did not stand completely upright due to the weight of the fouling algae and sediment, which is often also the case in a natural seagrass bed. This resulted in artificial seagrass leaves 'with food' sometimes harbouring lower fish abundances than seagrasses 'without food' (mainly Haemulon flavolineatum). When discussing the results, we have taken these artefacts into account and drawn conclusions accordingly. These differences had no effect on the general patterns and the conclusions of this study, because a comparison of fish abundances between artificial seagrass leaves with and without food is not made in the following paragraphs.

Herbivores were more abundant in EUs with food than in EUs without food (i.e. algae), dependent on the level of structure and presence of shade. The majority 
Table 3. Behaviour and location in the EUs per species of different feeding guilds. For each behaviour and location in the EU, percentages of cases are given, as counted by one trained observer. Numbers in bold represent values for the different feeding guilds, whereas values in plain text are for separate species within each guild. Grey areas indicate most frequent behaviour. D: diurnally active; N: nocturnally active; Total N: sum of fishes counted in all observation rounds by a single observer; Resting: at the bottom, in the middle, or on the top part of an EU; Foraging: from substratum (Sub), algae on artificial seagrass leaves (AS), or algae on artificial mangrove roots (AM); S: swimming through an EU; Other: other types of behaviour (for M. martinicus it indicates searching for food)

\begin{tabular}{|c|c|c|c|c|c|c|c|c|c|c|c|c|c|}
\hline \multirow{3}{*}{$\begin{array}{l}\begin{array}{l}\text { Scientific } \\
\text { name }\end{array} \\
\text { Herbivores (D) }\end{array}$} & \multirow{3}{*}{$\begin{array}{l}\text { Common } \\
\text { name }\end{array}$} & \multirow{3}{*}{$\begin{array}{c}\text { Total } \\
\mathrm{N}\end{array}$} & \multirow{3}{*}{$\begin{array}{l}\text { Size range } \\
\quad(\mathrm{cm})\end{array}$} & \multirow{2}{*}{\multicolumn{4}{|c|}{$\begin{array}{c}\text { Resting } \\
\text { All Bottom Middle Top }\end{array}$}} & \multicolumn{4}{|c|}{ Foraging } & \multirow[t]{2}{*}{$\mathrm{S}$} & \multirow[t]{2}{*}{ Other } \\
\hline & & & & & & & & All & Sub & $\mathrm{AS}$ & $\mathrm{AM}$ & & \\
\hline & & & & 11.3 & 8.4 & 1.6 & 1.4 & 80.4 & 10.3 & 19.5 & 50.6 & 8.2 & 0.2 \\
\hline Acanthurus chirurgus & Doctorfish & 36 & $7.5-22.5$ & 13.9 & 8.3 & 2.8 & 2.8 & 69.4 & 8.3 & 16.7 & 44.4 & 16.7 & - \\
\hline Acanthurus bahianus & Ocean surgeonfish & 398 & $5.0-22.5$ & 10.8 & 8.3 & 1.3 & 1.3 & 80.9 & 12.3 & 22.6 & 46.0 & 8.0 & 0.3 \\
\hline Scarus guacamaia & Rainbow parrotfish & 72 & $7.5-15.0$ & 2.8 & - & 1.4 & 1.4 & 91.7 & 1.4 & 5.6 & 84.7 & 5.6 & - \\
\hline Zoobenthivores (D) & & 381 & & 72.2 & 70.6 & 1.3 & 0.3 & 3.2 & 0.8 & 1.8 & 0.5 & 12.6 & 12.0 \\
\hline Eucinostomus spp. & $\begin{array}{l}\text { Slender mojarra \& } \\
\text { Silver jenny }\end{array}$ & 242 & $5.0-15.0$ & 87.6 & 86.0 & 1.2 & 0.4 & 2.1 & 1.2 & 0.8 & - & 10.3 & - \\
\hline Gerres cinereus & Yellowfin mojarra & 54 & $5.0-40.0$ & 87.0 & 85.2 & 1.9 & - & - & - & - & - & 13.0 & - \\
\hline Mulloidichthys martinicus & Yellow goatfish & 85 & $7.5-35.0$ & 18.8 & 17.6 & 1.2 & - & 8.3 & - & 5.9 & 2.4 & 18.8 & 54.1 \\
\hline Zoobenthivores (N) & & 1467 & & 94.9 & 85.8 & 0.8 & 8.3 & 1.0 & 0.5 & 0.2 & 0.2 & 3.0 & 1.2 \\
\hline Haemulon bonariense & Black grunt & 54 & $10.0-27.5$ & 35.2 & 35.2 & - & - & 9.3 & 9.3 & - & - & 53.7 & 1.9 \\
\hline Haemulon flavolineatum & French grunt & 808 & $2.5-12.5$ & 98.0 & 96.5 & 0.1 & 1.4 & 0.9 & 0.1 & 0.4 & 0.4 & - & 1.1 \\
\hline Haemulon sciurus & Bluestriped grunt & 9 & $10.0-22.5$ & 100.0 & 100.0 & - & - & - & - & - & - & - & - \\
\hline Lutjanus mahogoni & Mahogany snapper & r 263 & $2.5-12.5$ & 94.3 & 93.5 & 0.4 & 0.4 & 0.8 & 0.8 & - & - & 4.2 & 0.8 \\
\hline Lutjanus analis & Mutton snapper & 74 & $2.5-10.0$ & 95.9 & 95.9 & - & - & - & - & - & - & 1.4 & 2.7 \\
\hline Lutjanus apodus & Schoolmaster & 259 & $5.0-25.0$ & 97.7 & 51.4 & 3.9 & 42.5 & - & - & - & - & 1.2 & 1.2 \\
\hline \multicolumn{14}{|l|}{$\begin{array}{l}\text { Zoobenthivores/ } \\
\text { Zooplanktivores (N) }\end{array}$} \\
\hline Ocyurus chrysurus & Yellowtail snapper & 244 & $2.5-22.5$ & 80.7 & 38.1 & 29.1 & 13.5 & 0.8 & 0.4 & 0.4 & - & 18.0 & 0.4 \\
\hline \multicolumn{14}{|l|}{ Piscivores (D) } \\
\hline Sphyraena barracuda & Great barracuda & 660 & $2.5-47.5$ & 98.2 & 37.0 & 15.9 & 45.3 & - & - & - & - & 1.4 & 0.5 \\
\hline
\end{tabular}

of herbivores were feeding inside the EUs, and did so mostly in EUs with highest structural complexity (i.e. with artificial mangrove roots). These harboured higher herbivore abundances than empty EUs and EUs with artificial seagrass leaves, probably because the higher surface area of artificial mangrove roots provided more substrate for algae and thus more food. The attraction to algae was supported by the fact that unshaded EUs with AM appeared to harbour higher herbivore abundances than shaded EUs: the former possibly contained more algae due to the higher light intensities in the EUs, and therefore also more food. The experimental data thus suggest that juvenile herbivores utilise mangrove and seagrass habitats primarily as feeding habitats. In absence of algae, herbivores did not show any preference for presence or absence of structure. Although several studies have suggested that juvenile fish use structure provided by mangroves and seagrass beds as shelter (Orth et al. 1984, Jenkins \& Sutherland 1997, Cocheret de la Morinière et al. 2004), the present study indicates that is not the case for herbivores, which are diurnally active foragers.

Pooled diurnally active zoobenthivores showed no clear preference for any of the factors or their combinations, despite significant (interaction) effects. Eucinosto- mus spp., on the other hand, were more attracted to EUs with macrozoobenthos than without. Their abundances were comparable in all EUs with access to macrozoobenthos, irrespective of structure and shade. The experimental data thus suggest that these diurnally active species utilise mangroves and seagrass beds primarily as feeding habitats and not as shelter habitats. Nevertheless, these species were mainly observed resting in the EUs. However, because these species feed by taking sporadic bites, and because the behavioural observations were only snap-shots, the importance of feeding was underestimated in terms of duration.

Our results on herbivores and diurnally active zoobenthivores are in agreement with those of Laegdsgaard \& Johnson (2001), who found that artificial mangrove roots with fouling algae and associated invertebrates attracted significantly higher abundances of some juvenile fish species than structures cleaned of algal growth. Hence, it can be concluded that for several diurnally active herbivore and zoobenthivore species, Caribbean mangroves and seagrass beds function as foraging habitats, but are not used continously for shelter during daytime. This shelter may become temporarily important, however, when fishes are attacked by a predator (Laegdsgaard \& Johnson 2001). 
Nocturnally active zoobenthivores and zooplanktivores were attracted to the EUs during daytime by structure (occasionally in interaction with shade) and not by food. These species all shelter in structurally complex habitats during daytime and feed in the seagrass beds at night (e.g. Ogden \& Zieman 1977, Rooker \& Dennis 1991, Nagelkerken et al. 2000). Accordingly, in the present study they did not show elevated abundances in EUs with food (i.e. macrozoobenthos) and were observed resting instead of foraging during daytime. The significant interaction between food and structure found for most nocturnally active zoobenthivorous and zooplanktivorous species was due to the reduced structural complexity of artificial seagrass leaves fouled by algae (as explained in the first paragraph of 'Discussion'), which were not attractive to these species that were mostly observed to rest in between structurally complex areas. In the absence of shade, Haemulon flavolineatum, Lutjanus mahogoni, L. apodus and Ocyurus chrysurus showed highest abundances in any EU containing artificial seagrass leaves, and none favoured EUs with artificial mangrove roots only. This indicates that unshaded mangrove roots probably provide an unnatural shelter habitat that is not recognised by the fishes. In the presence of shade, EUs with artificial mangrove roots alone were indeed used by the fishes (except $H$. flavolineatum) to a similar extent as EUs with artificial seagrass leaves. When the unnatural unshaded artificial mangrove roots were not considered, species-specific patterns for habitat preference and shade could be distinguished. H. lavolineatum was attracted mainly by artificial seagrass leaves: its abundance was highest in any EU with artificial seagrass, and it was observed resting only in between the artificial leaves. The same was true for L. mahogoni in absence of shade, which also showed highest abundances in unshaded artificial seagrass (which is a natural situation for seagrass beds). However, in presence of shade, L. mahogoni occurred in equally high abundances in all habitat types. L. apodus and O. chrysurus did not show a different preference for either artificial mangrove roots or artificial seagrass leaves; when the former habitat type was present they were found in the top or middle of the EU (i.e. near or in between the artificial mangrove roots), when the latter habitat type was present they were found on the bottom of the EU (i.e. in between the artificial seagrass leaves), and when both were present they were found in either part of the EUs.

Many studies have shown that structural complexity reduces predation efficiency and offers shelter to both fish and shrimps (Heck \& Thoman 1981, Orth et al. 1984, Primavera 1997, Laegdsgaard \& Johnson 2001). In the latter study, for example, laboratory experiments were performed showing that juvenile fish avoided artificial mangrove pneumatophores when predators were absent, whereas they actively sought shelter inside the structure when predators were introduced. Furthermore, risk of predation was higher on bare mudflats than in structurally complex seagrasses and mangroves (Laegdsgaard \& Johnson 2001). So, in the present study, nocturnally active fish species that rested during daytime were very likely to use mangrove-like and seagrass-like structures as shelter, since the experiment took place in an environment where predators were not excluded.

The piscivore Sphyraena barracuda was only attracted to the EUs by structure. Regardless of presence of food (algae and macrozoobenthos, which are no food sources for this species) or shade. Abundances were higher in EUs with any type of structure than in empty EUs, suggesting that this species may not have a preference for seagrass beds over mangroves or vice versa. Indeed, in EUs with both seagrass leaves and mangrove roots, $S$. barracuda of equal percentages rested in between structures of both habitat types. Although smaller individuals of this species may have used the structure for shelter, larger individuals most likely used the structure for ambush to forage on sardines, anchovies, and silversides that were schooling around the EUs. This is supported by field observations showing that $S$. barracuda often roams around at the mangrove/seagrass interface in search of schools of these silverfish (Nagelkerken \& van der Velde 2004). High levels of structural complexity have been suggested to aid ambush predators by camouflaging them and decreasing their visibility to their prey (Heck \& Orth 1980, Coen et al. 1981, Howard \& Koehn 1985).

In contrast to other studies (Hair et al. 1994, Cocheret de la Morinière et al. 2004), our study suggests a relatively small effect of shade as a single factor. This may be due to the fact that light levels inside the shaded EUs were still 20 times higher than inside natural mangroves. Indeed, for visual predators, reductions in light intensities may influence prey detection and reduce predation rates only at very low light intensities (Benfield \& Minello 1996). However, the present study used similar light levels as the study of Cocheret de la Morinière et al. (2004), which was also conducted in the Spanish Water Bay. The fact that they found an effect of shade is perhaps caused by the placement of the EUs on an isolated seagrass bed far away from mangroves that offer high levels of shade, whereas our EUs were placed directly adjacent to mangroves.

\section{CONCLUSIONS}

Our experiments provided evidence that herbivorous fish probably use mangroves and seagrass beds during daytime primarily to feed on fouling algae and epiphytes. Diurnally active zoobenthivoric Eucinosto- 
mus spp. use mangroves and seagrass beds during daytime to feed on zoobenthos. Nocturnally active zoobenthivores/zooplanktivores primarily use seagrass and mangrove structures (in interaction with shade) during daytime to rest and shelter. The piscivore Sphyraena barracuda is probably attracted to mangroves and seagrass beds primarily by structure: larger-sized specimens use this to ambush their prey, while smaller-sized specimens may also use the structure for protection. The hierarchy in importance of the various factors clearly differed between feeding guilds and species. Overall, it can be concluded that during daytime the presence of structure, food and shade significantly contribute to the attractiveness of mangroves and seagrass beds to juvenile reef fish.

Acknowledgements. The Schure-Beijerinck-Popping Fonds funded the fieldwork of this study. I.N. was supported by an NWO-VIDI grant. D.d.G. and M.P. received funding from the Nijmegen University Fund (SNUF). We thank the staff and personnel of the Carmabi Foundation for their hospitality and provision of research materials. Asiento marina kindly provided dock space for our research boat. A. de Schryver is thanked for her help in building the experimental units. M. Vermeij is thanked for lending us his light meter. The Department of Animal Behaviour of the University of Groningen kindly provided office space for writing the manuscript. We also thank T. de Boo, H. Huber, J. Stuefer and J. M. van Groenendael of the Radboud University Nijmegen for statistical advice. This is Centre for Wetland Ecology publication number 362 .

\section{LITERATURE CITED}

Beck MW, Heck KL, Able KW, Childers DL and 9 others (2001) The identification, conservation, and management of estuarine and marine nurseries for fish and invertebrates. BioScience 51:633-641

Bell JD, Westoby M (1986) Abundance of macrofauna in dense seagrass is due to habitat preference, not predation. Oecologia 68:205-209

Benfield MC, Minello TJ (1996) Relative effects of turbidity and light intensity on reactive distance and feeding of an estuarine fish. Environ Biol Fish 46:211-216

Blaber SJM (2000) Tropical estuarine fishes. Ecology, exploitation and conservation. Fish and aquatic resources series 7. Blackwell Science, Oxford

Blaber SJM, Blaber TG (1980) Factors affecting the distribution of juvenile estuarine and inshore fish. J Fish Biol 17: 143-162

Carr WES, Adams CA (1973) Food habits of juvenile marine fishes occupying seagrass beds in the estuarine zone near Crystal River, Florida. Trans Am Fish Soc 102:511-540

Chittaro PM, Fryer BJ, Sale PF (2004) Discrimination of French grunts (Haemulon flavolineatum, Desmarest, 1823) from mangrove and coral reef habitats using otolith microchemistry. J Exp Mar Biol Ecol 308:169-183

Cocheret de la Morinière E, Nagelkerken I, van der Meij H, van der Velde G (2004) What attracts coral reef fish to mangroves: habitat complexity or shade? Mar Biol 144: 139-144
Coen LD, Heck KL Jr, Abele LG (1981) Experiments on competition and predation among shrimps of seagrass meadows. Ecology 62:1484-1493

de Haan D, Zaneveld JS (1959) Some notes on tides in Annabaai harbour, Curaçao, Netherlands Antilles. Bull Mar Sci Gulf Caribb 9:224-236

Edgar GJ (1999) Experimental analysis of structural versus trophic importance of seagrass beds. II. Effects on fishes, decapods and cephalopods. Vie Milieu Life Environ 49: 249-260

Gillanders BM, Able KW, Brown JA, Eggleston DB, Sheridan PF (2003) Evidence of connectivity between juvenile and adult habitats for mobile marine fauna: an important component of nurseries. Mar Ecol Prog Ser 247:281-295

Hair CA, Bell JD, Kingsford MJ (1994) Effects of position in the water column, vertical movement and shade on settlement of fish to artificial habitats. Bull Mar Sci 55:434-444

Heck KL Jr, Orth RJ (1980) Seagrass habitats: the roles of habitat complexity, competition and predation in structuring associated fish and motile macroinvertebrate assemblages. In: Kennedy VS (ed) Estuarine perspectives. Academic Press, New York, p 449-464

Heck KL Jr, Thoman TA (1981) Experiments on predator-prey interactions in vegetated aquatic habitats. J Exp Mar Biol Ecol 53:125-134

Heck KL, Hays G, Orth RJ (2003) Critical evaluation of the nursery role hypothesis for seagrass meadows. Mar Ecol Prog Ser 253:123-136

Helfman GS (1981) The advantage to fishes of hovering in shade. Copeia 2:392-400

Hindell JS, Jenkins GP, Keough MJ (2000) Evaluating the impact of predation by fish on the assemblage structure of fishes associated with seagrass (Heterozostera tasmanica) (Martens ex Ascherson) den Hartog, and unvegetated sand habitats. J Exp Mar Biol Ecol 255:153-174

Howard RK, Koehn JD (1985) Population dynamics and feeding ecology of pipefish (Syngnathidae) associated with Eelgrass beds of Western Port, Victoria. Aust J Mar Freshw Res 36:361-370

Howard RK, Edgar GJ, Hutchings PA (1989) Faunal assemblages of seagrass beds. In: Larkum AWD, McComb AJ, Shepherd SA (eds) Biology of seagrasses. Elsevier, Amsterdam, p 536-564

Jackson EL, Rowden AA, Attrill MJ, Bossey SJ, Jones MB (2001) The importance of seagrass beds as a habitat for fishery species. Oceanogr Mar Biol Annu Rev 39:269-303

James PL, Heck KL Jr (1994) The effects of habitat complexity and light intensity on ambush predation within a simulated seagrass habitat. J Exp Mar Biol Ecol 176:187-200

Jenkins GP, Sutherland CR (1997) The influence of habitat structure on nearshore fish assemblages in a southern Australian embayment: colonisation and turnover rate of fishes associated with artificial macrophyte beds of varying physical structure. J Exp Mar Biol Ecol 218:103-125

Laegdsgaard P, Johnson C (2001) Why do juvenile fish utilise mangrove habitats? J Exp Mar Biol Ecol 257:229-253

Levin PS, Hay ME (2003) Selection of estuarine habitats by juvenile gags in experimental mesocosms. Trans Am Fish Soc 132:76-83

Levin P, Petrik R, Malone J (1997) Interactive effects of habitat selection, food supply and predation on recruitment of an estuarine fish. Oecologia 112:55-63

Ley JA, Montague CL, McIvor CC (1994) Food habits of mangrove fishes: a comparison along estuarine gradients in northeastern Florida Bay. Bull Mar Sci 54:881-899

Macia A, Abrabtes KGS, Paula J (2003) Thorn fish Terapon jarbua (Forskål) predation on juvenile white shrimp 
Penaeus indicus H. Milne Edwards and brown shrimp Metapenaeus monoceros (Fabricius): the effect of turbidity, prey density, substrate type and pneumatophore density. J Exp Mar Biol Ecol 291:29-56

Main KL (1987) Predator avoidance in seagrass meadows: prey behavior, microhabitat selection, and cryptic coloration. Ecology 68:170-180

Mazur MM, Beauchamp DA (2003) A comparison of visual prey detection among species of piscivorous salmonids: effects of light and low turbidities. Environ Biol Fish 67: 397-405

McCartt AL, Lynch WE, Johnson DL (1997) How light, a predator, and experience influence bluegill use of shade and schooling. Environ Biol Fish 49:79-87

McCullagh P, Nelder JA (1989) Generalized linear models, 2nd edn. Chapman \& Hall, London

Nagelkerken I, van der Velde G (2004) Are Caribbean mangroves important feeding grounds for juvenile reef fish from adjacent seagrass beds? Mar Ecol Prog Ser 274: $143-151$

Nagelkerken I, Dorenbosch $M$, Verberk WCEP, de la Morinière EC, van der Velde G (2000) Day-night shifts of fishes between shallow-water biotopes of a Caribbean bay, with emphasis on the nocturnal feeding of Haemulidae and Lutjanidae. Mar Ecol Prog Ser 194:55-64

Odum WF, Heald EJ (1975) The detritus-based food web of an estuarine mangrove community. In: Cronin LE (ed) Estuarine research. Academic Press, New York, p 265-286

Ogden JC, Zieman JC (1977) Ecological aspects of coral reefseagrass bed contacts in the Caribbean. Proc 3rd Int Coral Reef Symp 1:377-382

Orth RJ, van Montfrans J (1984) Epiphyte-seagrass relationships with an emphasis on the role of micrograzing: a review. Aquat Bot 18:43-69

Orth RJ, Heck KL, van Montfrans J (1984) Faunal communities in seagrass beds: a review of the influence of plant structure and prey characteristics on predator-prey relationships. Estuaries 7:339-350

Parrish JD (1989) Fish communities of interacting shallowwater habitats in tropical oceanic regions. Mar Ecol Prog Ser 58:143-160

Editorial responsibility: Otto Kinne (Editor-in-Chief), Oldendorf/Luhe, Germany
Pollard DA (1984) A review of ecological studies on seagrassfish communities, with particular reference to recent studies in Australia. Aquat Bot 18:3-42

Primavera JH (1997) Fish predation on mangrove-associated penaeids. The role of structures and substrate. J Exp Mar Biol Ecol 215:205-216

Rajendran N, Kathiresan K (1999) Do decomposing leaves of mangroves attract fishes? Curr Sci 77:971-976

Randall JE (1967) Food habits of reef fishes in the West Indies. Stud Trop Oceanogr 5:665-847

Ronnback P, Troll M, Kautsky N, Primavera JH (1999) Distribution pattern of shrimps and fish among Avicennia and Rhizophora microhabitats in the Pagbilao mangroves, Philippines. Estuar Coast Shelf Sci 31:723-743

Rooker JR, Dennis GD (1991) Diel, lunar and seasonal changes in a mangrove fish assemblage off southwestern Puerto Rico. Bull Mar Sci 49:684-698

Rooker JR, Holt GJ, Holt SA (1998) Vulnerability of newly settled red drum (Sciaenops ocellatus) to predatory fish: is early-life survival enhanced by seagrass meadows? Mar Biol 131:145-151

Schulman MJ (1985) Recruitment of coral reef fishes: effects of distribution of predators and shelter. Ecology 66: 1056-1066

Sheaves M (2001) Are there really few piscivorous fishes in shallow estuarine habitats? Mar Ecol Prog Ser 222: 279-290

Stunz GW, Minello TJ (2001) Habitat-related predation on juvenile wild-caught and hatchery-reared red drum Sciaenops ocellatus (Linnaeus). J Exp Mar Biol Ecol 260: 13-25

Tomascik T, Mah AJ, Nontji A, Moosa MK (1997) (eds) The ecology of the Indonesian seas Vol 8, Part II. Periplus, Singapore

Upston J, Booth DJ (2003) Settlement and density of juvenile fish assemblages in natural, Zostera capricorni (Zosteraceae) and artificial seagrass beds. Environ Biol Fish 66: 91-97

Valentine JF, Heck KL Jr (1999) Seagrass herbivory: evidence for the continued grazing of marine grasses. Mar Ecol Prog Ser 176:291-302

Submitted: August 17, 2004; Accepted: July 23, 2005 Proofs received from author(s): December 4, 2005 